\title{
The Role of Leadership in Human Resource Management a Comparative Study of Specific Public and Private Sectors in Pakistan
}

\author{
Akbar Ali* \\ Dean, Multi Disipline, Degree Program \\ NUST, Karachi
}

\begin{abstract}
The fundamental problem of this study was to examine "The role of leadership in human resource management through comparison of public and private sectors in Pakistan" by evaluating the leadership in ten competencies. The sample was 115 leaders (assesses) which were assessed by 520 respondents (assessors) belonging to Airlines, Hospitals and Banks from both Public and Private Sector. Each of the manager / leader was evaluated by using 360 degree feed back assessment questionnaire. Statistical analyses were conducted using the SPSS statistical package. Outcome of this study pointed that there were statistically significant difference among score of leadership between Private and Public Sector organizations. The conclusion of the study indicated; a) Leadership at Private sector is performing better than Public Sector. b) The leadership score of private sector bank was significantly higher to public sector bank. c) The leadership score of private sector hospital was significantly higher as compared to the public sector hospital. d) The leadership score in public sector airline was significantly higher to the private sector airline. The findings also indicated to call upon Pakistani leaders at public sector hospitals and banks, as well as private sector airline leaders to enhance their competencies.
\end{abstract}

Keywords: $360^{\prime}$ degree, feedback, leader, peers, autocrat, delegation.

\section{INTRODUCTION}

Effective leadership is a personal role that requires the blending of motivational, strategic and management skills to align focus, energy and drive whilst creating a culture which encourages individual thinking and attainment. Ultimately leadership is about pushing ideas and thoughts forward, shouldering responsibility and aspirations to bring out the confidence of others. Leaders are required to have greater project leadership and influencing skills than in the past. Summary of some key leadership skills:

- Managerial - keep track of progress against targets and take action on slippage

- Trustworthy - speak honestly and openly and expect the same from others

- Aware - understand each individual's abilities, limitations, motives and drivers

- Influential - use vision, argument and important stakeholders to sway opinion

- Visionary - know what needs to be achieved and how to go about achieving it

- Inspirational - create and bring to life an image of how things can be

Cascio (1998) have narrated that 'Managing People' a Critical Role for Every Manager, and when it comes to managing people, all managers must be concerned to some degree

The material presented by the author does not necessarily portray the viewpoint of the editors and the management of the Institute of Business \& Technology (BIZTEK) or Nust, Karachi.

*Akbal Ali : leadership1969@yahoo.com

C JMSS is published by the Institute of Business and Technology (BIZTEK).

Main Ibrahim Hydri Road, Korangi Creek, Karachi-75190, Pakistan. 
The Role of Leadership in Human Resource Management a Comparative Study of Specific Public and Private Sectors in Pakistan

with the following five activities: staffing, retention, development, adjustment, and managing change:

a. Staffing comprises the activities of (1) identifying work requirements within an organization, (2) determining the numbers of people and the skills mix necessary to do the work, and (3) recruiting, selecting, and promoting qualified candidates.

b. Retention comprises the activities of (1) rewarding employees for reforming their jobs effectively, (2) ensuring harmonious working relations between employees and managers, and (3) maintaining a safe, healthy work environment.

c. Development is a function whose objective is to preserve and enhance employees' competence in their jobs through improving their knowledge, skills, abilities, and other characteristics; HR specialists use the term "competencies" to refer to those items.

d. Adjustment comprises activities intended to maintain compliance with the organization's HR policies (e.g., through discipline) and business strategies (e.g., cost leadership).

e. Managing Change is an ongoing process whose objective is to enhance the ability of an organization to anticipate and respond to developments in its external and internal environments, and to enable employees at all levels to cope with the changes.

Needles to say, these activities can be carried out at the individual, work team, or larger organizational unit (e.g., department) level. Sometimes they are intimated by the organization (e.g., recruitment efforts or management development programs), and sometimes they are initiated by the individual or work team (e.g., voluntary retirement, safety improvements). Whatever the case, the responsibilities for carrying out these activities are highly interrelated. Together, these activities constitute the HRM system.

\subsection{Objectives of the Study}

The objectives in the present study are to explore and understand the extent of role of leadership in organizations being played in relation to the HRM. The present research in its analysis will identify the following objectives:

(I) To study the role being played by HRM leadership.

(II) To carry out comparison and evaluation of management of public and private sector so that lesson drawn be used to fill in the gaps if any.

(III) To make recommendations for improving leadership and managerial performances as a means of organizational productivity and quality of work life in Pakistan.

(IV) To examine how leaders/managers actually perceive their leadership roles.

(V) To examine what actually is perceived about their leadership by their interactive individual

\subsection{Scope of Investigation}

Here need is felt to understand the specific objective encompassing 'Leadership role' at organizational level in public and private sector in Pakistan. For this purpose three very interactive areas have been considered for the study where it is felt paramount to evaluate the extent of performance being delivered by the leadership in the personnel or HRM department. It is also need of the hour to find out where private sector is performing better or government one and identifies the gaps if any, for improvement in future. Three sectors in focus are Banking, Hospitals and Airlines; where National Bank of Pakistan will be compared with Muslim Commercial Bank, Civil Hospital vs. Aga Khan and Pakistan International Airline vs. Aero Asia. There are numerous Reasons to target this segment of population are (I) covers huge area population (II) skillful and professional in nature (III) very interactive (IV) needs improvement.

\subsection{Statement of the Problem}

Present study upon the role of leadership in Human Resource Management deals with the responsibilities, functions, behaviors and importance of leadership. Previously managers used to be understood as leaders, but with the passage of time need were felt to change 
this terminology because words play role in all scenarios and situations. Therefore organizations throughout the world has felt the difference and agreed to incorporate the leadership concepts in their working environment and in HRM philosophy in particular.

This has also been experienced that leaders and managers at public sectors do not show the committed attitude as of private organizations, therefore it is found mandatory to focus our country so that a step towards the identification and filling of gaps be initiated. Some of the studies and personnel are in opinion that above assumption is even true at every country. Leadership role is supposed to be very inclined towards humanitarian factors. In Pakistan the issue of traditional management is required to be addressed to transform it to leadership conceptualization in true letter and spirit.

In Pakistan, this research is being conducted with the confidence that it will really bring a change in organizations. To assess the difference of performance at public and private sectors, three sectors have been chosen. Health (Hospital), finance (Banks) and communications, (Airlines). It is assumed this research will sufficiently deliver and show the picture of all the sectors. Here civil Hospital, PIA and NBP have been focused at public sectors as well as Aga Khan, Aero Asia and MCB from private Sectors. Comparison will provide the true picture of leadership performance and we will be able to know the gaps and how to fill them to bring a significant change in old culture, Psychology, perception and trends, we will learn how to lead and step forward towards bright future.

\subsection{Limitations / Challenges}

In the study herein proposed, the researcher notes the following limitations:

(I) This study was limited by respondents' knowledge and honesty about information related to leadership roles / behavior in Human Recourse Management.

(II) All respondents were full-time leaders / managers in public and private institutions. No part-time individual completed the Leader Behavior Description Questionnaire - in 360 degree leadership Survey.

(III) The results of the study were based upon perceptions of leaders and their interactive individuals within Karachi. Generalizations of these results are also appropriate for leaders outside of this city.

(IV) The study cannot account for personal attributes contributing towards leadership.

(V) The measurement of leadership behavior / role was based upon perceptions and was a limiting factor.

(VI) This study was limited by the normal problems related to leaders' behaviors associated with HRM departments and staff.

The study was taken as greet challenge as 360-degree evaluation is first time being carried out in Pakistan. Moreover it is not easy to get a manager assessed by his peers and subordinates. The extant which individual is playing its role as leader was to be assessed through ten competencies. So to evaluate a single person, the input / feed back from his peers subordinates and himself was to be considered, which was a real challenge in real life.

\section{HYPOTHESES}

The following Hypotheses were framed in the light of Research review and keeping in mind the prevailing culture of Pakistan:

(I) There will be Higher Average Scores on Human Resource Management - Leadership Roles, of Leaders in Private Sector Organizations as compared to Scores on Human Resource Management - Leadership Roles of Leaders in Public Sector Organizations.

(II) There will be Higher Average Scores on Human Resource Management - Leadership Roles, of Leaders in Private Sector Airline as compared to Scores on Human Resource Management - Leadership Roles of Leaders in Public Sector Airline. 
The Role of Leadership in Human Resource Management a Comparative Study of Specific Public and Private Sectors in Pakistan

(III) There will be Higher Average Scores on Human Resource Management - Leadership Roles, of Leaders in Private Sector Organization Hospital as compared to Scores on HRM - Leadership Roles of Leaders in Public Sector Hospital.

(IV) There will be Higher Average Scores on Human Resource Management - Leadership Roles, of Leaders in Private Sector Organization Bank as compared to Scores on HRM - Leadership Roles of Leaders in Public Sector Bank.

\section{LITERATURE REVIEW}

During course of research, a number of studies carried out previously by various researcher, were gone through as litacstrse review in the area of leadership roles in HRM. Detail of all ten in number the leadership role in terms of following compestences alongwith researchers are appended below:

3.1 Communication As Role: Leigh and Maynard (1994) narrated the importance of communication and wrote that vision that stays locked inside our head is useless. If we really care about our vision we will want to share it with others. Most effective managers are good communicators and leaders are even better at it. We may well need to refine our communication skills if we are to lead successfully. Dran (2004), Akerson and MAI (2003), Hammonds, Hargie, Tourish and Hargie (1994), West-Burnham (1997), Bennis, Parikh \& Lessem (1994), ,Kohles (2000) and Sage (2006) have worked upon the communication as Leadership Role and declared it as great skill.

3.1.1 Present study while decloring ammnication as an effective leader compentency also proved that private sector secured better score than of public sector (Table 1.3, No.2)

3.2 Learning: In a business environment of rapid change, many organizations seek to embrace organizational learning strategies to harness the abilities of all members. While considering learning as Leadership Role, Muthusamy and White (2005), London and Sessa (2006), Bristol (2003) Chan and Scott-Ladd (2004), Sosik, Godshalk and Yammarino (1999) worked a lot on the issue.

3.2.1 Our research also give due importance to learning as leadership role and he should ensure continuity of learning process of himself and for the leader at public airline obtained more score than private one, public hospital score> private hospital and private bank score> public bank.

3.3 Influence: Influence and power are inextricably linked. In fact, some scholars think that understanding power and the use of influence might be the most important concepts in all of leadership. Power is defined as the capacity to cause change. Influence is the degree of actual change in a target person's attitude, values, beliefs, or behaviors and same was researched out by the scholars like Clark (1999), Hemlin (2006), Musella and Leithwood, (1988), McDonald, Michael, Gooding and Cart. (2005), Galo. (2001) and Letendre, Henry and ToIan (2003).

3.3.1 Due environmental factors in Pakistan, we observed diversity in assessment of organizational leader.

3.4 Confidence: Kwok et. al. (2000), Lambrecht et. al. (1997), Bolger, Pulford and Colman (2000), Sadler (1970) and Jong Ruyter (2006) researched on confidence and proved it as leadership role. Leaders in Pvt Banks and hospitals were more confident than of public sector whereas airlines case was opposite.

3.5 Knowledge: In the Sage (2005) role of leader it is expected that he is a man of knowledge and wisdom. He performs as follows:

- Develops wisdom by expanding knowledge about wide-ranging. 
- Sees order and patterns where others only see chaos.

- Designs strategy by being cognizant of the past, present, and possible.

- Sustains curiosity and ongoing learning.

- Remains open to new ideas and ways of thinking.

- Is energized to understand complex, ambiguous situations and find the best path. Hurley and Green (2005) ,Berry (2003), Ahn, Jae-Hyeon \& Chang, Suk-Gown (2004), Mahoney, (2001), Politis (2002) and Paul Iles, Yolles Altman (2003) established that leaders must maintain the competency in knowledge.

3.6 Strategy: Cornelius et. al. (2002) has determined that a leader must take on certain "roles" to be truly effective. In its "Strategic" capacity, the leadership group spends time working on issues of long-term importance, including common policies, common direction, and organizational development/improvement initiatives. When the team works together strategically, they focus on issues that involve the long-term survival and/or growth of the business, as well as issues that will improve the day-to-day running of the business. Over time, these efforts work to reduce the number and severity of daily crises.

Recent studies have shown that Australian human resource management (HRM) has taken on a 'strategic' status. Implicit in these studies is the need for practitioners to effectively manage both macro and micro environmental challenges. Successful repositioning of the HRM function suggests that practitioners must perform three major roles, categorized as (i) strategic; (ii) consultancy; and (iii) service roles. Pajunen (2006), Cornelius et. al. (2002), Magdaraog (2003) and Tarafdar, Vaidya Hienemann (2006) have also proved a great leader should work out strategies to achieve good results in organization.

3.7 Priorities: A leader should be capable to prioritize the activities and same was supported by Gibson, Martin and Singer (2004), Gibson, Martin and Singer, 2004), Holmes (2002), Fisher (2004), James (2003), Yamuna Ako (2002) Webster (1997) and Baodong Liu (2004)

3.8 Relationships: Shakeela (2004) assessed independent dimensions of leadership behavior with an adapted version of an instrument that was designed to capture two dimensions of leadership: (1) initiating structure or task, and (2) consideration or relationship. The results obtained from a sample of 409 managers from the Maldives and Mauritius; reveal that the respondents identified five dimensions of managerial leadership behavior instead of the two that were expected. Panam (2004) while explaining 'Relationship building' expresses it as a leadership role which is the sum of five sub roles which include supporting, harmonizing, energizing, tension relieving and facilitating. A good leader/Manager should be able to establish and maintain cordial relationships with the people in organization and same was proved by Rajagopalan, Rasheed, and Datta (1993), Schwenk (1995), Eby (2004), and Schleich (2003).

3.9 Integrity: Webster's (2006) New Collegiate Dictionary defines integrity as firm adherence to a code of values or the quality or state of being complete or undivided. How does this translate to the business world? Leadership experts Dr. Gay Hendricks and Dr. Kate Ludeman cite in their book The Corporate Mystic, "the mastery of integrity comes down to three things: being authentic with yourself, being authentic with others, and doing the things you have said you would do". Integrity has been declared a great skill by Storr (2004), Petric (2000).

3.10 Delegation: Management strategies for directors and others involved with the management suggest ways to effectively delegate authority and tasks in order to reduce administrative pressures and workload. Abe and Babylon (2005), Zhang et. al. (2006), Hayden (1999), Genrich et. al. (2001), Bredeson (1995) and Osborne (1984). have also established that good leaders delegate to subordinates. 
The Role of Leadership in Human Resource Management a Comparative Study of Specific Public and Private Sectors in Pakistan

\section{METHODOLOGY}

\subsection{Study Design}

The study on Leadership role in Human Resource Procedure Management is being an emerging subject in Pakistan, to be viewed as Descriptive-Exploratory Research. It is termed as exploratory in the sense that there has been no prior research on the topic in Pakistan whereas it is descriptive because HRM departments have been working as personnel department or admin department along with its management comprising of managers as leaders in the organizations since decades in the country. What is leadership, its role and its assessment in HRM is therefore, covered under the exploratory discussion. The research involved formulation of leadership assessment questionnaire based on 360o Feedback system, literature search, identification of target population, selection of research sample, data collection and its analysis, interpretation, conclusion and recommendation as depicted in Fig. 1.1 below:

Fig. 1.1

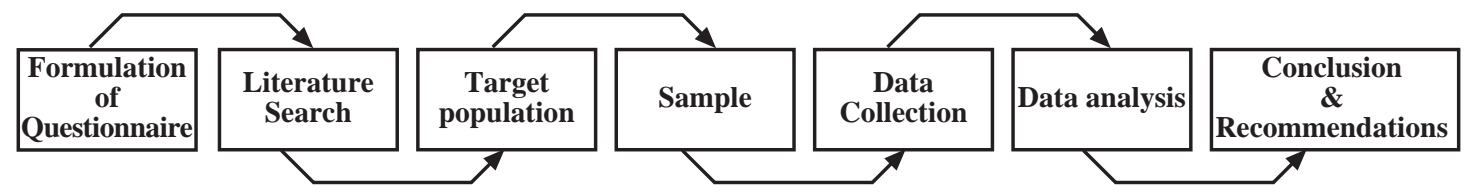

\section{4..2 Universe of Study}

The universe of study is the public and private sector organizations, in Pakistan. Six organizations comprising of three in public and three in private sector, have been chosen as universe. The departments under study are located in Karachi - Pakistan. Karachi is capital of province of Sindh and the largest city of the country in terms of population as well as education.

\subsection{Target Population}

The target population comprises of Human Resource Management departments of two banks, one at the public sector named as National Bank of Pakistan (NBP) compared to one at private sector named Muslim Commercial Bank of Pakistan (MCB). Civil Hospital HRM / personnel department has been compared with the same of Aga Khan Hospital / University HRM department. HRM department of Pakistan International Air Line has been assessed, compared to HRM of Aero Asia Airlines. As in Table 1.1 below; 115 leaders were assessed by themselves for supervisor, 162 peers and 141 subordinates:

Table 1.1

\begin{tabular}{|c|l|c|c|c|c|c|}
\hline \multirow{2}{*}{ S.No } & \multirow{2}{*}{ Organization } & \multirow{2}{*}{$\begin{array}{l}\text { Leaders/ } \\
\text { Assessees }\end{array}$} & & \multicolumn{4}{|c|}{ Assessors } \\
\cline { 4 - 7 } & & & Self & Supervisor/ Boss & Peer & Subordinate \\
\hline 1. & Aero Asia & 06 & 06 & 02 & 06 & 12 \\
\hline 2. & P I A & 15 & 15 & 14 & 19 & 19 \\
\hline 3. & Agha Khan Hospital & 11 & 11 & 10 & 19 & 18 \\
\hline 4. & Civil Hospital & 10 & 10 & 10 & 20 & 18 \\
\hline 5. & M C B & 25 & 25 & 24 & 42 & 20 \\
\hline 6. & N B P & 48 & 48 & 42 & 56 & 54 \\
\hline & Total & 115 & 115 & 102 & 162 & 141 \\
\hline
\end{tabular}

Total Assesses: 115

Total Assessors: 520 


\subsection{Sampling}

All the officers /managers / leaders available in Human Resource Management Department have been evaluated and assessed against the very new and innovative tool first time being used in Pakistan known as "360 degree feedback assessment system". Questionnaires have been got filled in by the total 520 assessors (superior, peers, subordinates and himself) officers / leaders. Table. 1.2 below shows the status accordingly: Ten competences each which are communication, learning, influence, confidence, knowledge, strategy, priorities, relationships, integrity and delegation.

Table 1.2

\begin{tabular}{|c|l|c|c|c|}
\hline S. No. & Organization & $\begin{array}{c}\text { No of Officers } \\
\text { (Assesses) }\end{array}$ & $\begin{array}{c}\text { No. of } \\
\text { Assessors }\end{array}$ & $\begin{array}{c}\text { Roles / } \\
\text { be Assessed }\end{array}$ \\
\hline 1. & Aero Asia & 06 & 26 & 60 \\
\hline 2. & PIA & 15 & 67 & 150 \\
\hline 3. & Aga Khan Hospital & 11 & 58 & 110 \\
\hline 4. & Civil Hospital & 10 & 58 & 100 \\
\hline 5. & MCB & 25 & 111 & 250 \\
\hline 6. & NBP & 48 & 200 & 480 \\
\hline
\end{tabular}

\subsection{Tool / Used For Study}

An instrument as a questionnaire was used for this study which is called "360 Degree Leadership tool" authored by Gorham (2002). Primary goal of this program is to improve organizational leadership through input of assessment by person's superiors, subordinates and peers. By surveying up, down and across (360 Degree) we can provide leaders / participants / organizations with information unobtainable from conventional assessment instruments. This activity is totally anonymous, no personal information is asked. The instrument / tool is a 43 items questionnaire encompassing ten very famous leadership behaviours / competencies to be assessed which are, Communication, Learning, Influence, Confidence, Knowledge, Strategy, Priorities, Relationships, Integrity and Delegation.

\subsection{Statistical Analysis Tool}

The data was statistically analyzed by SPSS version 11 for results through Mean Comparison t-test.

\subsection{Assessment Procedure}

Each of the leader / manager was assessed by himself, his senior, peers and subordinates against the leadership roles / competencies (Table 1.3) upon the concept of 360 - degree evaluation. Then after summing up all, average score was considered. Subsequently sum of all the leaders in organization was calculated and then mean was scored which was taken as leadership score of organization. Similarly all the organizations were assessed. Table 1.3 (S.No. 12) provides the picture of mean score of each of the organization. 
The Role of Leadership in Human Resource Management a Comparative Study of Specific Public and Private Sectors in Pakistan

\section{RESULTS}

Table 1.3

\begin{tabular}{|c|l|c|c|c|c|c|c|}
\hline $\begin{array}{c}\text { S. } \\
\text { No }\end{array}$ & \multicolumn{1}{|c|}{$\begin{array}{c}\text { Role / } \\
\text { Competences }\end{array}$} & $\begin{array}{c}\text { Pvt } \\
\text { Airline }\end{array}$ & $\begin{array}{c}\text { Public } \\
\text { Airline }\end{array}$ & $\begin{array}{c}\text { Pvt } \\
\text { Hospital }\end{array}$ & $\begin{array}{c}\text { Public } \\
\text { Hospital }\end{array}$ & $\begin{array}{c}\text { Pvt } \\
\text { Bank }\end{array}$ & $\begin{array}{c}\text { Public } \\
\text { Bank }\end{array}$ \\
\hline 1 & Strategy & 3.7 & 3.99 & 4.16 & 3.17 & 4.44 & 4.22 \\
\hline 2 & Communication & 3.68 & 3.38 & 4.14 & 3.94 & 4.31 & 3.95 \\
\hline 3 & Knowledge & 4.21 & 4.31 & 4.44 & 4.45 & 4.60 & 4.31 \\
\hline 4 & Learning & 3.83 & 4.39 & 4.52 & 4.63 & 4.59 & 4.24 \\
\hline 5 & Influence & 4.09 & 4.38 & 4.55 & 4.59 & 4.58 & 4.36 \\
\hline 6 & Relation ship & 3.99 & 4.21 & 4.61 & 4.52 & 4.64 & 4.34 \\
\hline 7 & Delegation & 3.26 & 3.22 & 3.75 & 3.48 & 4.03 & 3.26 \\
\hline 8 & Priorities & 4.73 & 4.46 & 4.52 & 4.67 & 4.60 & 4.56 \\
\hline 9 & Integrity & 4.28 & 4.35 & 4.57 & 4.75 & 4.60 & 4.35 \\
\hline 10 & Confidence & 3.68 & 3.86 & 4.37 & 4.17 & 4.17 & 3.98 \\
\hline 11 & Over all & 39.45 & 40.92 & 43.63 & 42.46 & 44.61 & 41.58 \\
\hline 12 & Mean & 3.94 & 4.092 & 4.36 & 4.245 & 4.46 & 4.15 \\
\hline
\end{tabular}

Figure - 1.2

Organizations

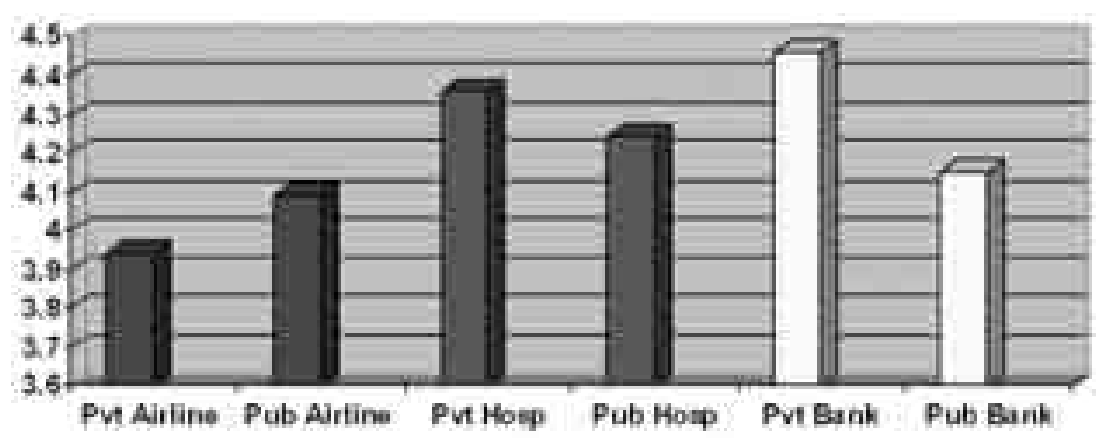

Table - 1.4

\begin{tabular}{|c|l|c|c|}
\hline S. No & Organizations & $\begin{array}{c}\text { Private } \\
\text { Organization }\end{array}$ & $\begin{array}{c}\text { Public } \\
\text { Organization }\end{array}$ \\
\hline 1 & Airline & 3.94 & 4.092 \\
\hline 2 & Hospital & 4.36 & 4.245 \\
\hline 3 & Bank & 4.46 & 4.15 \\
\hline 4 & Overall & 12.76 & 12.487 \\
\hline 5 & Mean & $\mathbf{4 . 2 5}$ & $\mathbf{4 . 1 6}$ \\
\hline
\end{tabular}


Fig - 1.3

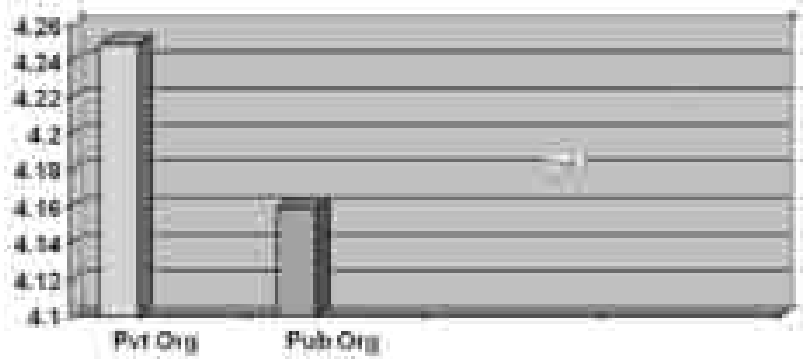

Table 1.5 (a)

T-Test; Showing Mean difference in leadership competencies in Private and Public Sector Airlines/ Banks / Hospitals

\begin{tabular}{|c|c|c|c|c|}
\hline & id & Shanh & S11. Crevehing. & $\begin{array}{l}\text { 9tst Error } \\
\text { Mano }\end{array}$ \\
\hline RAPVTTL & 90 & 40330 & 41238 & 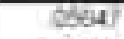 \\
\hline Praptigat. & 150 & 42010 & cabst & Otose \\
\hline ANCUENTHE & stis & +3846 & 20511 & $245 i 4$ \\
\hline CA.PuElO & 100 & 42580 & 50875 & co6t \\
\hline MCEP-TEK & 250 & A 44EE & 47913 & 03030 \\
\hline ILPPUEAx & ang & 43385 & 초연 & $\cos 2$ \\
\hline
\end{tabular}

Table 1.5 (b)

One Sample Test; comparing t - Leadership Competencies among All Six Private and Public Sector Organizations

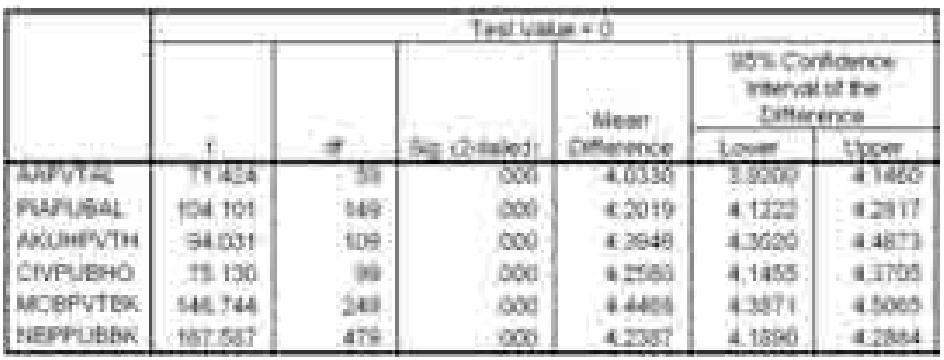

Graph 1.4

Showing Mean (Average) values on HRM - Leadership Roles among All Six Private and Public Sector Organizations

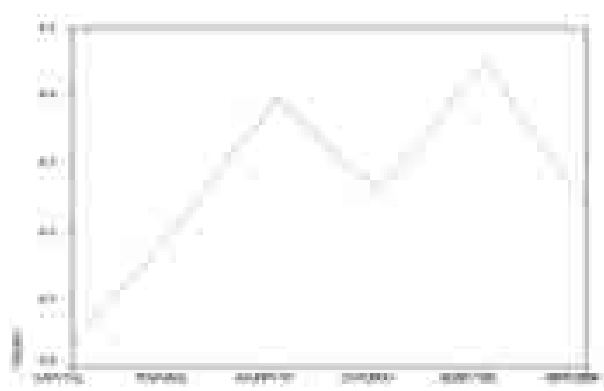


The Role of Leadership in Human Resource Management a Comparative Study of Specific Public and Private Sectors in Pakistan

\section{DISCUSSION}

\subsection{Findings}

a. Private Organization leadership is performing better than public sector organizations i.e. (Table 1.4).

b. Private Bank leadership's performance has been assessed greater than Public Bank (Table 1.3).

c. Private Hospital leadership secured better score than of Public Hospital (Table 1.3).

d. Private sector airline's performance has been assessed as weaker than public airline contrary to hypothesis (Table 1.3).

e. Comparison through T-test, the value of mean and $\mathrm{T}$ have also proved all the above findings (Table $1.5 \mathrm{a} / \mathrm{b}$, Graph 1.4).

f. All the hypothesis have been proved except hypothesis-II (Airlines case).

\subsection{Discussion}

a) Hospitals. Reasons, for better performance by private sector leadership than public are appended below:

1. Private Hospital is working upon International standards, Integrating physician and nonphysician roles across all functional areas of the organization to improve functional, quality, operational and clinical outcomes whereas public Hospital works upon local standards.

2. Private Hospital applies specific criteria and vigorous processes that enable it to identify, recruit, select and train physicians to be effective leaders. On the other hand motivational factors are seldom applied within the government hospital.

3. Immediate action oriented check and balance system exists in private hospital, while public sector is lacking in such accountability. Balance between authority and responsibility exists to a great extent in private hospital against the non existence of the same in public sector.

4. Higher salaries / incentives demand more work and motivation in private sector whereas lesser benefits lead towards inefficiency in playing of leadership roles within the public sector hospital.

5. Private hospital incorporates different leadership styles to facilitate acceptance of integration and improves team effectiveness, whereas public sector very seldom allows innovations and dominating authorities believe less in motivating the team and more in ordering and forceful implementation of the required performance.

6. Private Hospital provides proper education and training, as well as a rigorous selection and recruitment process. Their physician leaders are making significant contributions to their healthcare organization, to help make it safer, more efficient and more profitable.

7. Private Hospital believes in positive human relationships when it comes to HRM concerns.

b) Banks. HRM Leadership in Private Sector Bank scores higher than Public Sector Bank, it might be as a corollary to the following:

1. Transparent recruitment and selection of staff and officers.

2. Better working environment and conducive atmosphere at all levels.

3. Attractive salaries and incentives.

4. Higher motivation.

5. Continuous and continual training and courses i.e on job training.

6. Maintenance of International standards. 
7. More educated employees.

8. Innovative and flexible policies in vogue.

9. More competitive and challenging objectives in hand.

10. Leaders supports and prefer the concept of participative / democratic leadership instead of bossing or autocratic style.

c) Airlines. The reasons of unexpected results opposite to hypothesis might be:

1. Private Sector Airlines is operating at very small scale being a very small organization as compared to Public Airlines which is enormous in size.

2. Private Sector Airlines is still in its developing stage and quite new in the field whereas Public Sector Airline has been operating since very long and is very established Airlines.

3. The infrastructure of HRM in Private Sector Airline is at very initial stage whereas HRM department at Public Sector Airline is well established and running on innovative principles

d) Some Other Reasons For Better Results At Private Sector. The experiences during data assimilation of the study reveal the following Reasons of better leadership performance in Private Sector:

1. Transparent and innovative system of recruitment and induction of employees.

2. Better and extensive training facilities and chances.

3. Programmed / designated on job training and courses.

4. Strategies implemented to provide mental relaxation within the environment.

5. Audit and control system is standardized.

6. The 'time management' in private organization is implemented.

7. Private sector is working under innovative concept of efficiency / effectiveness.

8. Since it is owned by individual / groups of business people, therefore productivity i.e. output / input is always considered greater.

9. Flexibility in ideas and procedure implementation.

10. New Technology is given preference.

11. Effective and prompt means of communications are used.

12. Personal welfare and efficiency of employees leads to better out put.

13. The atmospheric competitiveness prevails.

14. Cultural diversity is accepted in private organization more than in government.

15. There is an excellent feedback and accountability system.

16. Probability of misuse of power is less.

17. Cross cultural growth is preferred where employee can survive easily.

\section{CONCLUSION \& RECOMMENDATIONS}

\subsection{Conclusion}

The conclusion of the study indicated; a) Leadership performance at Private sector is higher then Public sector organization. b) The leadership roles in private sector bank were significantly higher on all the ten competencies as compared to public sector bank. Results are evident in this regard. c) The leadership roles in private sector hospital were significantly higher on strategy, communication, relationships, delegation and confidence as compared to the public sector hospital. d) The leadership roles in public sector airline were significantly higher on strategy, knowledge, learning, influence, relationship, integrity and confidence as compared to the private sector airline. Findings further report that 360-degree assessment tool provides more accurate and justified evaluation of an individual's competencies to judge his performance as a leader. Further it has been concluded that leadership development is an essential element to improve the organizational infrastructure. Training of public and private sector professionals must incorporate leadership skills and knowledge to augment the overall competency of the workforce. Despite all concerns, we believe that the enhancement of Leadership Role and Competency is a unique and groundbreaking 
The Role of Leadership in Human Resource Management a Comparative Study of Specific Public and Private Sectors in Pakistan

contribution that can be used by both public and private sector organizations. Developing qualified and able public and private sector leaders is a critical step in building the infrastructure needed to address organizational challenges in both the sectors.

\section{Recommendations}

1. To improve the quality of HRM, the paradigm shift from Manager to Leadership is essential in all the public and private sector organizations. Within public sector, the leadership style is still Hegemonic / Autocrat and has not entered the area of International phenomenon of leadership till to date. There is need to switch over participative and democratic style of leadership.

2. Organizations should ensure that communication process should flow in all directions, upward, downward, in parallel just as of concept of 360 degree Feedback to reach out desired results.

3. Leadership needs assessment for improvement. For improvement of behavior skill and traits of personality to perform better leadership roles, frequent use of 3600 feedback assessment should be made in organizations.

4. In ?Developing pay systems and other incentives, the public sector is not usually able to compete with the salaries offered by private employers, especially those of highlyeducated personnel and managers. However, pay increases may be necessary to prevent an outflow of highly-qualified personnel.

5. Regular monitoring and evaluation of strategic actions is a crucial part of the process and is a tool for continuing development and improvement. This tool should judicially be utilized in every organization.

6. Public and Private sector Bank's Leaders in Pakistan need to compete and excel across ten common competencies / roles which will provide subsequent outcome of better human service:

7. The Public and Private sector Airline Leaders in Pakistan need to be trained for improvement of their leadership competencies which will result into performance of HR activities in better way.

8. The Public and Private sector Hospital Leaders in Pakistan must be able to engage in new thinking and help executive management to develop new directions to successfully compete in an increasingly challenging environment. They need to explore strategies to measure progress through a set of "vital signs" and continually redirect the organization to respond to change and opportunity. Hospital CEOs and their boards must build and sustain vibrant, trust-based relationships in order to successfully navigate the opportunities and challenges in today's complex and fast-paced healthcare world. Trust is a result of high integrity, clear and consistent communication, well-defined roles and responsibilities, and well-articulated performance expectations and accountabilities. Hence they need to explore the dynamics of building a board/CEO relationship where the best skills and resources of each are used to develop synergistic leadership that inspires confidence and drives high performance.

\section{REFERENCES:}

Abe, Gary K.., \& Babylon, William T. (2005). "Delegation-A Competency of Superior Performers", Naval Postgraduate School Monterey CA. at; http://www.stormingmedia.us/authors/Babylon_William_T_htm

Ahn, Jae-Hyeon \& Chang, Suk-Gwon (2004). "Knowledge management technique", Decision Support Systems Archive, Volume 36, Issue 4 March. pp. 403 - 416.

Akerson, Alan, Mai, Robert (2003). "The leader as Communicator", AMACON Printer, American Management Association, USA.P.38.

Baodong Liu, (2004). "Economic development priorities at the city-administrator level", American Politics Research, Vol. 32, No. 6, pp. 698-721.

Bennis, W., Parikh, J. \& Lessem, R. (1994). "Beyond Leadership: Balancing Economics, Ethics and Ecology", Blackwill Publishers, The publishing imprint of Basil Blackwell Inc. available at; www.aare.edu.au/00pap/yeu00429-htm

Berry, Heather (2003). "Leader laggard and the Pursuit of Foreign Knowledge", SMJ03 5291 Revision 2, Heather Berry; Department of Management, The Wharton School 
2022 Steinberg Hall-Dietrich Hall University of Pennsylvania. Philadelphia.

Bolger, Fergus., Pulford, Briony D. \&. Colman, Andrew M. (2000). "The conditions of a competitive market are simulated in a game", University of Leicester and Fergus Bolger University of Durham at; Inferential Expectation.htm.

Bredeson, Paul V. (1995). "Superintendents' Roles in Curriculum Development and Instructional Leadership", available at; http://portal.acm.org/results.cfm?

Bristol, George. (2003). Evaluation in capacity building, Graduate School of Education, University of Bristol, pp. 1.

Cascio, Wayne, F. (1998). "Managing Human Resources", Craig Beytien, the McGrow Hill Companies, Inc. New York USA P. 20. available at; http://www.mhhe.com.

Chan, Christopher C. A. \& Scott-Ladd, Brend A. (2004). "Organizational Learning", Asia pacific Journal of Human Resources, Vol. 42, No. 3, pp. 336-347.

Clark, Andy. (1999). "Leadership and Influence: The Manager as Coach, Nanny and Artificial DNA", Jossey-Bass: San Francisco, at; http://hdl.handle.net/1842/1309 Edinburgh Research Archive Item 1842-1309.htm

Convis, Gary L. (2004). "The nine roles of the value driven leader", Sage to Artisan' at; hyperlimk http://www.1eading.net/choosemqain.htm

Cornelius \& Associates. (2002). "Long-term Strategic Leadership", available at; http://www.corneliusassoc.com/CA/new/impact/February2002/LdadershipVision.htm

Cornelius \& associates. (2002). "Long-term Strategic Leadership", available at; http://www.corneliusassoc.com/CA/new/impact/February2002/LdadershipVision.htm

Dran, Gisela Von. (2004). "Roles of a leader", Sysacrase University, available at; www.ffos.hr/lida/lida2004/ppt/subota/LIDA_2004_Gisela_von_Dran.ppt+leader+ roles+in+hrm\%22ppt $22 \& \mathrm{hl}=\mathrm{en} \& \mathrm{ie}=\mathrm{Utf}-8$

Eby, Lillian T. (2004). Mentorship effectiveness, Department of Psychology, The University of Georgia, Athens, GA 30602, USA. P.102.

Fisher, Graham. (2004). "Contemporary debates about the nature and purpose of ocial and educational research", unpublished Ph.D, Graduate School of Education, University of Bristol, pp. 1 - 2

Galo, Glynn. (2001). "The management and leadership roles of Solomon Islands head teachers: perceptions, priorities and practices", Glynn Galo, Graduate School of Education, University of Bristol, pp 05-07.

Genrich, Sandra J., Banks, J. Carolyn., Bufton, Karen., Savage, Mary ellen., OWENS, Marcella, Upshaw. (2001). "Group Involvement in Decision Making", Journal of Continuing Education in Nursing, vol.32 No.1 Jan-Feb. pp. 20-26.

Gibson, Jennifer L., Martine, Douglas K. \& Singer, Peter A. (2004). "Setting priorities in health care organizations", Bio-Med, Published 8 September. 1. University of Toronto Ontario, M5G 1L4 Canada. Available at; http://www.biomedcentral.com/content/pdf/1472-6963-4-25.pdf

Gorham, Richard. (2002). "Tools for the Successful Leader - 360 Degree Leadership tool", available at; http://www.Leadership-Tools.com.

Hammonds, Bruce. (2004). "The Key role of leadership", New Plymouth, New Zealand. at; http://www.leading-learning.co.nz

Hargie, C., Tourish, D., \& hargie, O. (1994). "Managers Communicating: An Investigation of Core Situations and Difficulties within Educational organizations", International Journal of Educational Management, 8 (6) pp. 23-8.

Hayden, Jacqueline. (1999). "Delegation: Win - Win Strategies for Managing early childhood settings", AECA Research in Practice Series, Vol. 6, No.1. Australian Early Childhood Association available at www.dea.org.au.

Hemlin, Sven. (2006). "Creative knowledge environments for research groups in biotech", Scientometrics, Volume 67, Number 1, April, pp.121-142(22).

Holmes, Keith. (2002). "The potential and limitations of post-compulsory education in the Overseas Territories of the UK, with particular reference to the Cayman Islands and Montserrat", unpublished Ph.D, Graduate School of Education, University of Bristol, pp.1.

Hurley, Tracy A. \& Green, Carolyn W. (2005). "Knowledge Management (KM) programs", Journal of Knowledge Management Practice, January. Texas A \& M University- 
The Role of Leadership in Human Resource Management a Comparative Study of Specific Public and Private Sectors in Pakistan

Kingsville, San Antonio pp 1.

Iles, Paul., Yolles, Maurice \& Altman., Yochanan. (2003). Knowledge Workers, at; www.KnowledgeResearch and Practice in Human Resource Management.htm

James, Mark. (2003). "Evaluating rural primary education development programs in low income countries: a comparative study of the nature and process of evaluatory activities and their role in improving quality", unpublished Ph.D, Mark James; Graduate School of Education, University of Bristol, pp. 2 - 3.

Jong, Ad De \& Ruyter, Ko De. (2006). "Self-Managing Services", Journal of the Academy of Marketing Science, Vol. 34, No. 4, pp. 576-587.

Kohles, Jeffery C. (2000). The vision Integration Process: Leadership, Communication and A Reconceptulization of vision (2nd edition), Pearson Professional Ltd. available at www.aare.edu.au/00pap/yeu00429-htm

Kwok, Man-Ieung., lo, Sai-Kwong., Ng, Man-Biu \& Cheng, Yin-Cheong. (1997). "New and experienced Secondary School Principals: Leadership, Management Difficulties, Confidence, Efficacy and Statisfaction", Educational Research Journal. Vol 12 No.1, summer.,pp. 60 - 72

Lambrecht, Judith J., Hopkins, Charles R., Moss, Jerome, Jr., \& Finch, Curtis r. (1997). "Importance of On-the job Experiences in Developing Leadership Capabilities", NCRVE Materials Distribution Service, Horrabin Hall 46, Western Illinois,University, Macomb, IL 61455.

Leigh, Andrew \& Maynard, Michael. (1991). The Perfect Leader, Random House Business Books, London, U.K.p.46.

Letendre, Joan., Henry, david \& Tolan, Patrick H. (2003). "Education level of the leader". Research on Social Work Practice, Vol. 13, No. 5, pp. 569-587.

London AND Sessa (2006). "Group Feedback for Continuous Learning", Human Resource Development Review, Vol. 5, No. 3, pp. 303-329.

Lorna, Storr. (2004). "Leading with Integrity a qualitative research study", Journal of Health, Organization and Management, Volume 18, Number 6, pp. 415-434(20),

Magdaraog, Victor. (2003). "CIO Leadership Roles", A study by Philippine Computer Society at; http://www.itnetcentntra.com.

Mahoney, Janet. (2001). "Leadership for the 21st Century", Journal of Nursing Management, Vol 9, pp. 269-271.

Mcdonald, J., Michael, Gooding, \& Cart, W. (2005). "Leadership and upward influence: A survey of business school deans", Southern Business Review, Spring, pp 31-45

Muthusamy, Senthil K. \& White, Margaret A. (2005). "Learning and knowledge transfer in strategic Alliances: A Social Exchange view", Organization Studies, Vol. 26, No. 3 , pp.415-441.

Musella, Donald and Leithwood, Kenneth. (1988). "Influence of chief education officers on school effecting". Peabody Journal of education, Vol. 65, No. 4

Osborne, W . Larry. (1984). "Who's in Charge Here. The what and how of Leadership", available at; www.leadership.htm.

Pajunen, Kalle. (2006). "The More Thing Change, the More Remain the Same? Evaluating Strategic Leadership in Organizational Transfer", Leadership, Vol. 2, No. 3, pp. 341 366.

Panam. (2004). "Relationship building", The McGraw-Hill Companies, Inc. at; http://www.coba.panam.edu/faculty/brewerton/3361/|Chap014.ppt.

Petric, Joseph A. (2000). "The Challenger of Leadership Accountability for Integrity capacity as a Strategic Asset", Journal Business Ethics, vol 3-4, December pp. 330 343.

Politis, John. (2002). "Knowledge acquisitions attributes in UAE Organizations", at; hyperlink ftp://ntftp.pearsoned-ema.com/HEE_Samples/SampleChapters/ 0273688766.pdf

Rajagopalan, Rasheed, \& Datta. (1993). "Integrative models of strategic decision-making", Journal of Management, Vol. 29, No. 4, pp. 469-486

Sadler, Philip J. (1970). "Four leadership styles", The Journal of Applied Behavioral Science, Vol. 6, No. 1, pp. 3-19.

Sage Publications. (2006). "Behavior and team performance", Organization Management, 
Vol. 31, No.. 2, pp 180-211.

Schleich, David John. (2003). "The Canadian College of Naturopathic Medicine President's Office", A Healthy Life Practices Strategy for Community College, Canada. Schwenk. (1995). "Decision-Making in North American Managers", Journal of Management, Vol. 29, No. 4, pp. 469-486.

Shakeela, M. (2004). "A Measure of Leadership Behavior: Does the Age - Old Measure Require Redefining?", Research and Practice in Human Resource Management, 12(2), PP. 140-151 \& Journal of Management, Vol. 26, No. 5, 2000, pp. 863-883.

Sosik, J. J., Godshalk, V. M, \& yammarino, F. J. (1999). "Transformational leadership, learning goal orientation, and expectations for career success in mentor-protégé relationships: A multiple levels of analysis perspective", The Leadership Quarterly.

SPSS. (2002). "Accounting and Statistics", GSO Version v11. Disc Combat, Digital Rom. Storr, Lorna. (2004). "Leading with Integrity a qualitative research study", Journal of Health, Organization and Management, Volume 18, Number 6, pp. 415-434(20),

Tarafdar, Monideepa., Vaidya, Sanjiv d., \& Heinemann, Butterworth. (2006). "Organizational and Strategic Imperatives", The Journal of Strategic Information Systems archive, Volume 15, Issue 4, December, pp. 293-326 at; http://portal.acm.org/results.cfm?

Webster, Thomas Kuli. (1997). "International and national influences on universal primary education policies, with specific reference to Papua New Guinea", Unpublished Ed.D, Thomas Kuli Webster; Graduate School of Education, University of Bristol, available at; www.bris.ac.uk/education/people/academicStaff/edmwc/research_students

Webster's. (2006). "The Effective Leadership", New Collegiate Dictionary, at; http://www.elsevier.com/wps/find/bookdescription.cws_home/637430/description

West-Burnham, J. (1997). Managing Quality in Schools (2nd edition), Pearson Professional Ltd. available at; www.aare.edu.au/00pap/yeu00429-htm

Worden, Skip. (2004). "Crisis of confidence in executive leadership in corporate America", Journal of Business Ethics, Humanities, Social Sciences and Law, December 15 pp. 31-44.

Yamuna Ako, Willy. (2002)."Factors affecting the formulation and implementation of the 1993 Educational Reform in Papua New Guinea", Unpublished Ed.D ,Willy Yamuna Ako, Graduate School of Education, University of Bristol, available at; http://sas space.sas.ac.uk/dspace/bitstream/10065/313/12/oceania.xml.

Zhang, Suling., Tremaine, Marilyn., Fjermestad, Jerry., Milewski, Allen \& O'sullivan, Patrick .(2006). "Delegation in Virtual Team", Proceedings of the IEEE International Conference on Global Software Engineering (ICGSE'06), ISBN:0-7695-2663-2. IEEE Computer Society Washington, DC, USA at; http://portal.acm.org/results.cfm? 